\title{
Effect of rock phosphate and plant growth-promoting rhizobacteria on physical and chemical properties change of corn residues during composting.
}

\author{
Rasslan, M.N. ${ }^{1}$, S.M. Mahmoud ${ }^{2}$, H.M. Mohamed $^{2}$ and A.A.A. Basha ${ }^{1}{ }^{*}$ \\ ${ }^{I}$ Department of Soil and Water, Faculty of Agriculture, South Valley University, Qena, Egypt \\ ${ }^{2}$ Department of Soil and Water, Faculty of Agriculture, Assiut University, Assiut, Egypt
}

\begin{abstract}
This study aims to study the effect of adding rock phosphate and plant growth-promoting rhizobacteria (PGPR), in the physical and chemical properties of the corn residues compost during aerobic decomposition. Four composting heaps were included in this study as it follows, 1) traditional method composting heap (T1), 2) heap was supplied with rock phosphate (T2), 3) heap was supplied with rock phosphate + Bacillus megatherum culture (T3), and 4) heap was supplied with rock phosphate+(Bacillus.megatherum, Azospirillum lipoferum, Azotobacter chroococcum) mixed cultures (T4). All compost treatments showed an increase in temperature right after composting started. The heap treated with three bacterial inoculums (T4) reached the highest peak values of $62.2^{\circ} \mathrm{C}$ on day 12 compared to other treatments. At the end of the composting period $\mathrm{T} 1$ recorded the lowest value of bulk density $\left(533 \mathrm{~kg} / \mathrm{m}^{3}\right)$ compared to other treatments. The $\mathrm{pH}$ value declined to stabilize with the end result at 100 days being 6.9, 7.4, 7.1 and 7.0 for composting treatment T1, T2, T3 and T4, respectively. The initial $\mathrm{C} / \mathrm{N}$ ratio was $61: 1$ for all composting treatments, and the final values of total $\mathrm{C} / \mathrm{N}$ ratio after the 100 days were 15:1, 14:1, 12:1 and 10:1 for composting treatments T1, T2, T3 and T4 respectively. Compost supplied with rock phosphate and three bacterial inoculums (T4) reached has more N, P and K content compared to other composting treatments $\mathrm{T} 1, \mathrm{~T} 2, \mathrm{~T} 3$. These results indicated that adding rock phosphate and (PGPR) to corn residues during composting improve nutritional value of the resulting compost.
\end{abstract}

Keywords: Composting; Growth promoter; Rock phosphate; Corn residues.

\section{Introduction}

In 2012 Egypt produced about 35 million tons per year of agricultural residues about 21 million tons of agricultural wastes per year (plant and animal) are left without avail and Corn residues account for about 5.65 million tons per year (16.1\%) at ratio. in Egypt, maize, sorghum, rice and cotton crops. Such crops represent the largest crops from which the most wastes about10.34 million tons, that are not taken advantage of, are resulted, moreover,

\footnotetext{
*Corresponding author: M. N., Rasslan

Email: mohamednafieraslan@gmail.com

Received: March 27, 2021; Accepted: June 8, 2021;

Published online: June 18, 2021.

(C) Published by South Valley University.

This is an open access article licensed under c(i) (2)
}

by recycling these wastes, the economic return of farms can be increased and the environment can be protected from pollution (Hassan et al., 2014). Incorporation of plant residues in agricultural soils is primarily a means to sustain soil organic matter content, and improve physical properties, increase nutrients' availability and enhance the biological activity (Smith et al., 1993). Recycling of agricultural wastes for crop production is an acquisition, in recent years because of lack of nutrients and high cost of chemical fertilizers (Biswas, 2011).

Composting is a well-known form of organic waste stabilization, where conditions may be created which allows the natural occurrence of thermophilic temperatures, under 
particular conditions of moisture and aeration (Rodrigues et al., 1995) compost value depends on the quality of the substrate. Nevertheless, composts prepared from farm wastes have low nutrient content, particularly potassium (K) and phosphorus (P) and are considered poor suppliers of nutrients to crops. Composting is an effective and environmentally friendly method to stabilize organic wastes, inactivate pathogens, and recycle nutrients (Zhang and Sun, 2015). During the preparation of composting, animal manure should be mixed with plant residues to adjust the C: $\mathrm{N}$ Ratio to be around 30:1 (Preusch et al., 2004).

A possible means of improving the nutrient content in compost to prepare enriched compost by addition of rock phosphate (RP), waste mica and some benefit microbes (Narayanasamy and Biswas, 1998). The use of some beneficial bacteria with P-enriched compost in an incorporated manner improves the growth and yield in chickpea (Shahzad et al., 2008).Plant growth promoting rhizobacteria (PGPR) are important inoculants for integrated nutrient management which help in dissolving inorganic $\mathrm{P}$ by excreting organic acids and chelation to release $\mathrm{P}$ in soil solution (Adesemoye et al., 2008). It was reported that there are several PGPR inoculants currently commercialized that promote growth either by improved nutrient acquisition, fixing atmospheric nitrogen, solubilizing insoluble phosphates, suppression of plant disease, or phytohormone production (Khan and Bano, 2016). The use of rock phosphate (RP) as an alternative for $\mathrm{P}$ fertilizer is gaining attention in sustainable agriculture through microbial solubilization (Reddy et al., 2002) and preparation of RP-enriched compost (Achal et al., 2007). The mixing of RP with organic materials such as animal feces, plant residues and inoculation with acid-producing microbes may enhance $\mathrm{P}$ solubility from RP because when organic materials decompose, more soluble $\mathrm{P}$ is released due to the action of organic acids produced by the microbes (Puente et al., 2004). The incorporation of organic residues either singly or in conjunction with a cheap source of mining element as rock phosphate may help to improve soil quality and productivity (Gaind et al., 2006). Rock phosphate enriched compost which was solubilized by phosphate solubilizing fungi and applied on a mung-bean crop, significantly enhanced yield and P-uptake (Shrivastava et al., 2011). Therefore, this study aims to evaluate the effect of rock phosphate and plant growth-promoting rhizobacteria, follow and understand the changes in the physical and chemical properties of the corn residues compost during aerobic decomposition.

\section{Materials and Methods}

\subsection{Raw materials}

\subsubsection{Plant residues}

The corn crop (Zea mays L.) its stalks and leaves were collected from some farms in Qena Governorate. The corn residues were air dried and chopped into small pieces $(2-3 \mathrm{~cm}$ length) by the waste mincer.

\subsubsection{Cattle dung}

Cattle dung was obtained from the Animal Production Farm at the Faculty of Agriculture, South Valley University, it was added at rate $250 \mathrm{~kg} / \mathrm{t}$ corn residues as a source of degrading microorganisms. Some Characteristics of raw materials are presented (Table 1). 
Table 1. Characteristics of corn residues and cattle manure.

\begin{tabular}{ccc}
\hline & Waste type & \\
Characters & Corn residues & Cattle manure \\
\hline $\mathrm{pH}(1-10)$ & 5.4 & 8.7 \\
Ec (1-10) ds/m & 4 & 4.5 \\
Moisture content $(\%)$ & 6.81 & 84.4 \\
Organic matter (\%) & 95 & 71 \\
Organic C (\%) & 55 & 41.18 \\
C/N Ratio & 105 & 32 \\
Ash (\%) & 5 & 29 \\
Total N (\%) & 0.52 & 1.27 \\
Total P $(\%)$ & 0.002 & 0.47 \\
Total K $(\%)$ & 0.2 & 0.88 \\
Bulk density kg/m & 210 & 433 \\
\hline
\end{tabular}

\subsection{Rock Phosphate}

Rock Phosphate (RP) obtained from ElSebaiya site mines $\left(25^{\circ} 10^{\prime} 30^{\prime \prime} \mathrm{N} 32^{\circ} 40^{\prime} 43^{\prime \prime} \mathrm{E}\right)$ Aswan Governorate, Egypt. The ground (RP) crushed and sieved to pass through a (270 mesh) contained $31.8 \% \mathrm{P}_{2} \mathrm{O}_{5}$, it was added at a rate of $145 \mathrm{~kg} / \mathrm{t}$ corn residues.

\subsection{Plant growth promoting rhizobacteria (PGPR)}

Three strains of PGPR: Azospirillum lipoferum, Azotobacter chroococcum and Bacillus megatherum were used to inoculate some treatments of compost heaps. A. chrococcum and A.lipoferum strains were obtained from Biofertilizer Unit, Faculty of Agriculture, South Valley University, Qena, Egypt. B. megatherum strain was obtained from the Microbial Resource Centre, Faculty of Agriculture, Ain Shams University.

\subsection{Chemical activator}

A chemical activator mixture was added at a rate $30 \mathrm{~kg}$ ammonium sulphate, $20.5 \%+15 \mathrm{Kg}$ superphosphate $15.5 \%+15 \mathrm{Kg}$ Calcium carbonate/t corn residues.

\subsection{Composting treatments}

Compost was prepared in the four heaps which have a size of $1 \mathrm{~m}$ width, $2 \mathrm{~m}$ long and $1.25 \mathrm{~m}$ height under the study were constructed four treatments as the following:

T1-Compost 1: Whereas, traditional method composting was used as a control (corn residues + fresh cattle dung + chemical activator)

T2-Compost 2: Corn residues+ cattle dung + chemical activator+ rock phosphate at $2 \% \mathrm{P}$. 
T3-Compost 3: Corn residues+ cattle dung + chemical activator+ rock phosphate at $2 \% \mathrm{P}+$ B. megatherum culture.

T4-Compost 4: Corn residues + cattle dung + chemical activator+ rock phosphate at $2 \% \mathrm{P}+$ (B.megatherum, A.lipoferum, A. chroococcum) mixed cultures.

\subsection{Preparing of PGPR inoculants}

Bacterial strains (A.lipoferum, A. chroococcum and B.megatherum) were separately grown in three fermentors each containing 10 liters of molasses medium $(50 \mathrm{ml}$ molasses $+5 \mathrm{~g}$ peptone $/ 1000 \mathrm{ml}$ distilled water), at $28-30{ }^{\circ} \mathrm{C}$ for 5 days. The counted numbers of viable cells in cultures at the time of use for compost inoculation were $1.7 \times 10^{8}$, $2.3 \times 10^{8}$ and $1.1 \times 10^{8}$ for A. lipoferum, $A$. chroococcum and $B$. megatherum, respectively. The inoculants were added at rate 10 litters/t residues. The compost heaps were inoculated with bacterial inoculants at the curing phase when the temperature had steadied around 40 ${ }^{\circ} \mathrm{C}$ (30 days of composting period). In the mixed treatment (T4), equal volumes of the three cultures were mixed before adding to the compost heap (Hamid et al., 2020).

\subsection{Heap formation}

Corn residues ( $2-3 \mathrm{~cm}$ length) were thoroughly mixed for homogenization purpose, and four heaps were prepared. A heap of the corn residues of $1.5 \mathrm{~m}$ long, $1.0 \mathrm{~m}$ width and $1.0 \mathrm{~m}$ height were made for the composting process. In all heaps the moisture content was adjusted to reach about $60 \%$ of their water holding capacity. The composting process could continue for 100 days, including the maturation period. The heaps were turned for aeration every 7 days of composting time. Eventually, the heap was covered with banana leaves to prevent the fast drying of the residues.

\subsection{Compost analysis}

Samples were collected from 3 points of the composting heap every 10 days and were kept in a deep freezer at $4{ }^{\circ} \mathrm{C}$ in a refrigerator for analyses. The phsico-chemical properties of collected samples during the composting process were determined as follows:

Temperature of the composting heap was measured daily using the thermometer stainless steel at different points of an area at a depth of $60 \mathrm{~cm}$ according to (Juárez et al., 2015). $\mathrm{pH}$ value was measured in a suspension compost/distilled water ratio 1:5 (w/v) using glass electrode Jenway $3510 \mathrm{pH}$ Meter (Smith et al., 2002). The electrical conductivity was determined in an extract compost/distilled water ratio 1:10 (w/v) using 4510 conductivity meter (JENWAY, UK) (Sánchez-Monedero et al., 2001). Moisture content was determined by forced-air ovens at $105^{\circ} \mathrm{C}$ for $24 \mathrm{hr}$. (Lazcano et al., 2008). Organic matter was determined by weight loss on ignition at $550^{\circ} \mathrm{C}$ for $4 \mathrm{~h}$ (Møller et al., 2000). Bulk density was determined according to (Huerta-Pujol et al., 2010). Total nitrogen was measured using Kjeldahl digestion method (Jackson, 1973), the ratio between nitrogen to carbon content of the compost samples was calculated according to the following procedure: $\mathrm{C}: \mathrm{N}$ ratio $=\%$ Carbon Content $\div \%$ Nitrogen Content. Acid solution of the digested compost sample was used for determination of total phosphorus and potassium (Page et al., 1982).

\section{Results and Discussion}

\subsection{Changes in Physical and chemical properties during composting process Temperature}

Changes in temperature of four different composting treatments are shown in 
(Fig 1). In general, all treatments show an increase in temperature right after composting started. All heaps rapidly arrived at the thermophilic phase on day 2 (more than $52^{\circ} \mathrm{C}$ ). After first turning (at day 7), the temperatures increased again and during heap turning, some temperature may lose. The occurrence of losses of heap temperature during mixing composting material in every week was also reported by (Qian et al., 2014). The heap treated with three bacterial inoculums (T4) reached the highest peak values of $62.2^{\circ} \mathrm{C}$ on day 12 compared to composting treatments $\mathrm{T} 1, \mathrm{~T} 2$ and $\mathrm{T} 3$, for which it was 54.5, 58.5 and $58.6{ }^{\circ} \mathrm{C}$, respectively. This increase in temperature in the treatment $\mathrm{T} 4$ compared to other treatments may be due to an increase in microbial activity, which increased the rate of organic matter decomposition (Hanajima et al., 2006). Figure 1 shows that the temperature gradually decreased afterwards and finally stabilized near the ambient temperature at 55-60 days for all composting treatments. This result is in accordance with those of other investigators (Liu et al., 2011 and Kutsanedzie et al., 2012).

\subsubsection{Changes in compost Bulk Density (BD)}

The data shown in Fig. 2 Show the amount of change in compost bulk density during the compost. There is an inverse relationship between the compost bulk density and the compost period due to the decomposition of the organic components and the loss of substrates during the compost, as reported by (Larney et al., 2000). The data shows, at the end of the composting period $\mathrm{T} 1$ recorded the lowest value $\left(533 \mathrm{~kg} / \mathrm{m}^{3}\right)$ compared to other treatments. This result may be due to additional RP for making the mixtures at initial time before composting for treatments T2, T3 and T4. Higher rates of bulk density indicate an increase in mass and a reduction of porosity and air capacity. In contrast, very little bulk density can imply extreme substrate aeration indirectly and a droplet in the available water portion (Nappi and Barberis, 1992). Raviv et al. (1987) mentioned that as the composting process length, the general particle size shifted from larger to smaller particles.

\subsubsection{Changes in pH}

Data in Fig. 3. Showed that on the 10th day of composting the $\mathrm{pH}$ of compost arrived at its peak value which is clearly related to temperature, also maybe caused to encourage $\mathrm{NH}_{3}$ production during composting (Spencer and Van Heyst, 2013). The $\mathrm{pH}$ value declined to stabilize with the end result at 100 days being 6.9, 7.4, 7.1 and 7.0 for composting treatment T1, T2, T3 and T4, respectively. This indicates a good quality compost and within the suggested range of 6-8.5, as has been reported by (Fogarty and Tuovinen, 1991). The decrease in $\mathrm{pH}$ during the first period of composting is expected because of the acids formed during the metabolism of readily available carbohydrates (Gautam et al., 2010). The $\mathrm{pH}$ rises above neutral because the acids are consumed by microorganisms and ammonium is produced from protein degradation.

\subsubsection{Changes in the electrical conductivity (EC)}

The impacts of 100 days of composting on the EC of heaps are shown in fig. 4. EC described the contents of soluble salt through the composting, the first values of 
Figure 1. Changes in temperature during composting process.

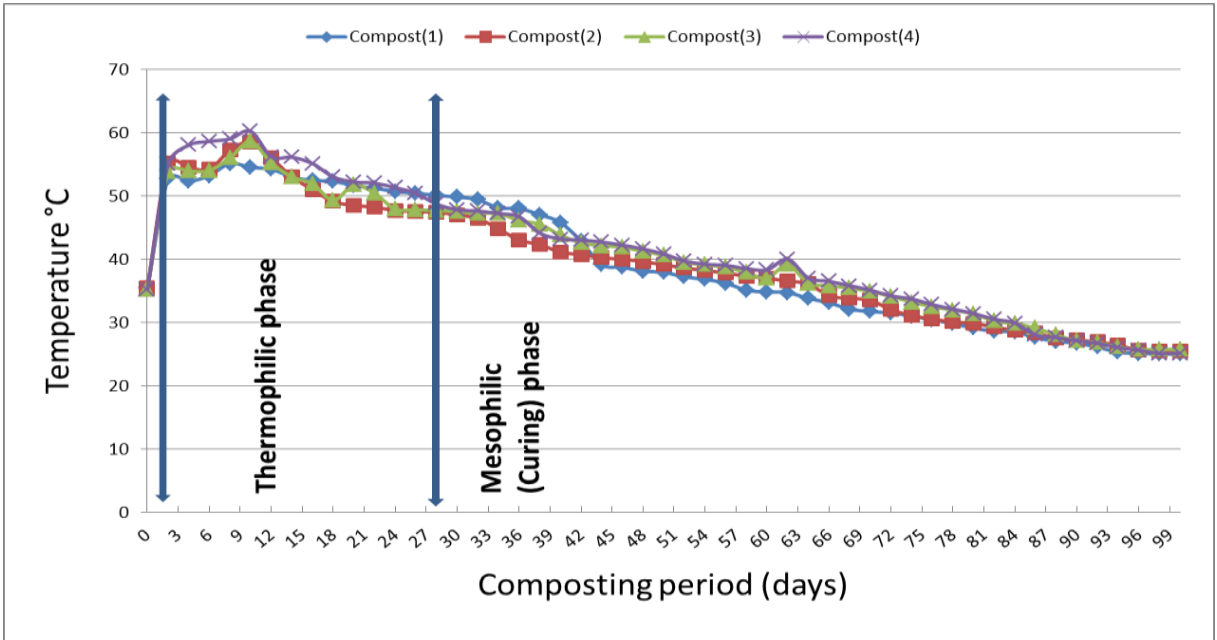

Figure 2. Changes in (BD) of compost heaps during composting.

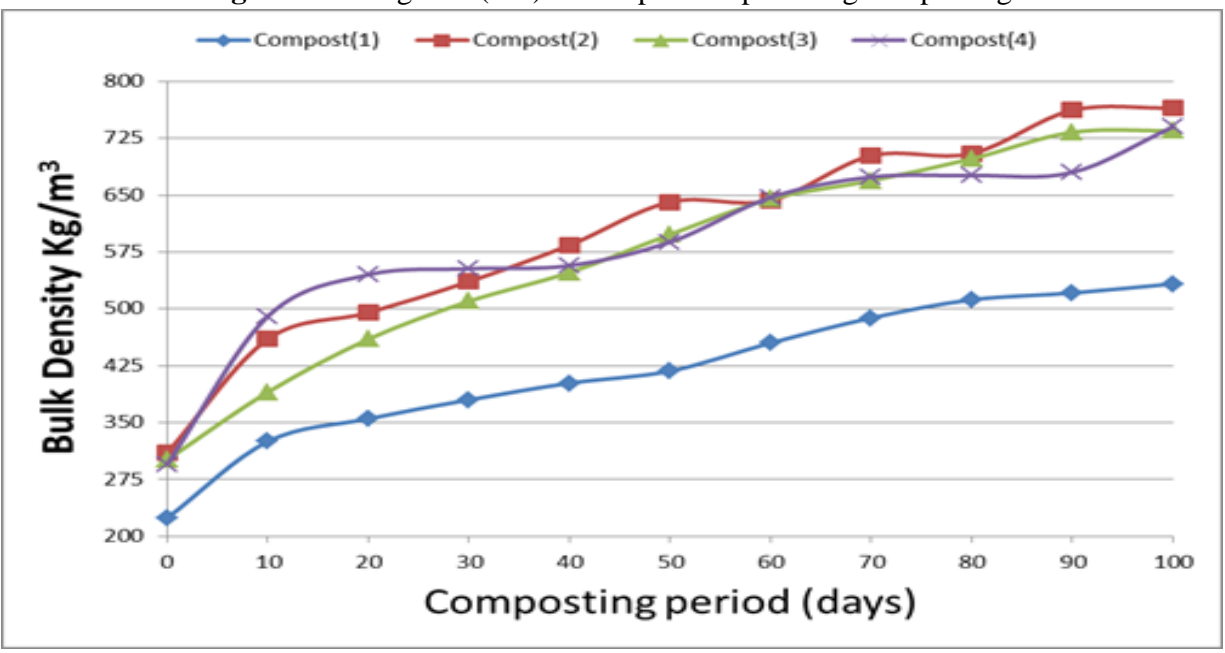

Figure 3. Changes in $\mathrm{pH}$ of compost heaps during composting.

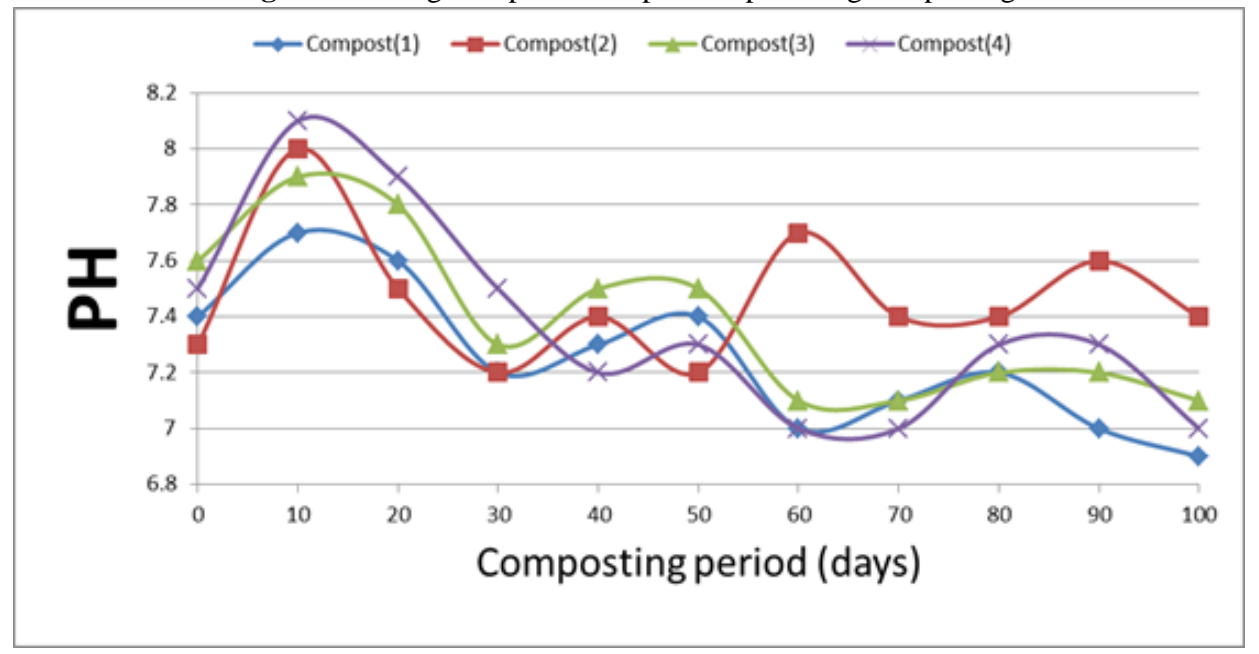


Figure 4. Changes in EC of compost heaps during composting

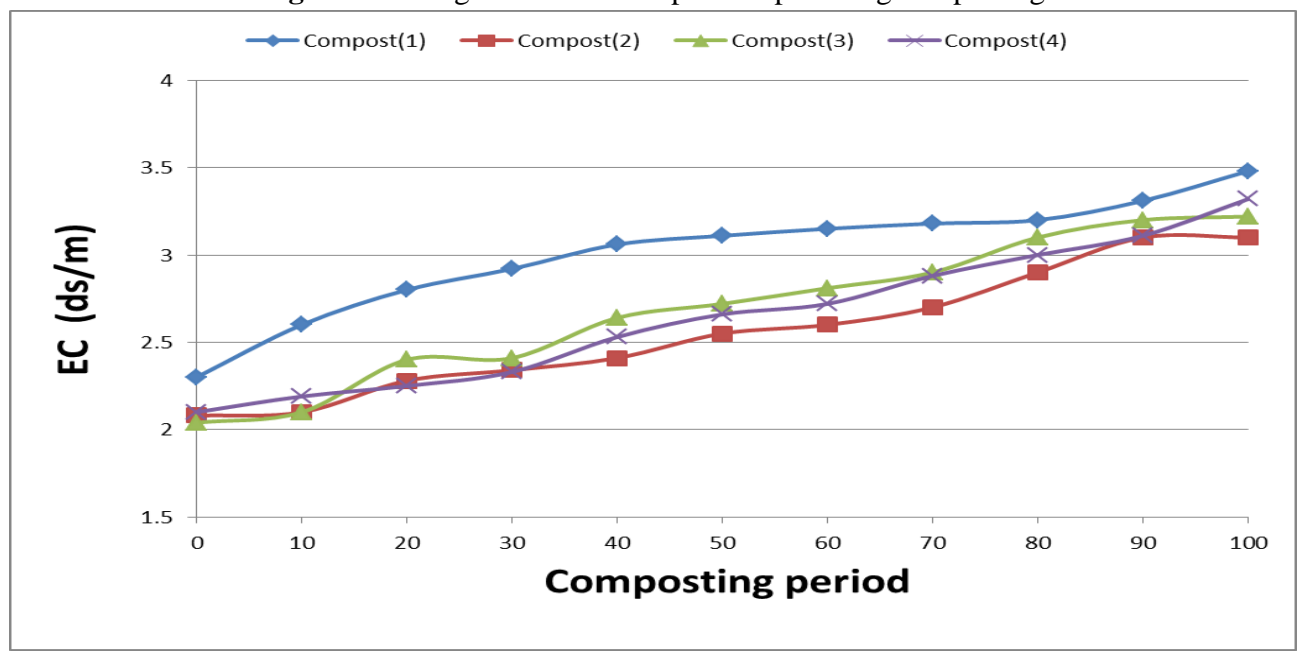

Figure 5. Changes in (TOC) of composting treatments with time.

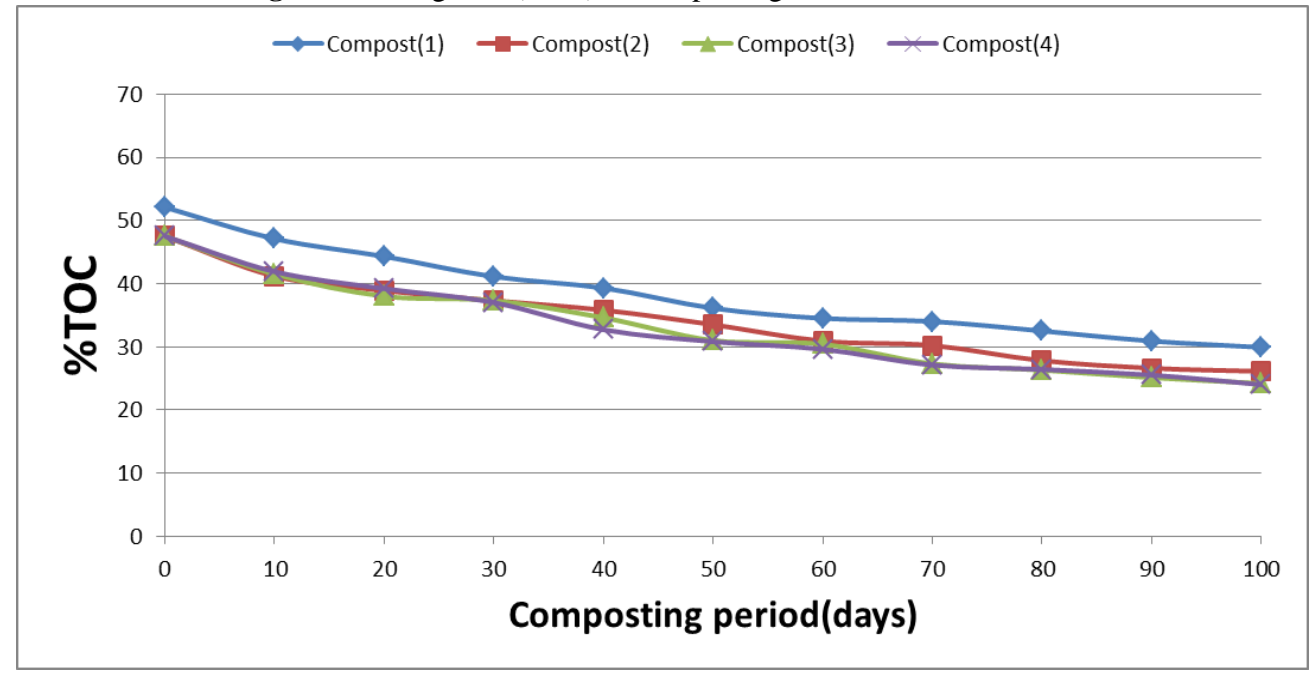

Figure 6. Changes in total nitrogen of composting treatments with time.

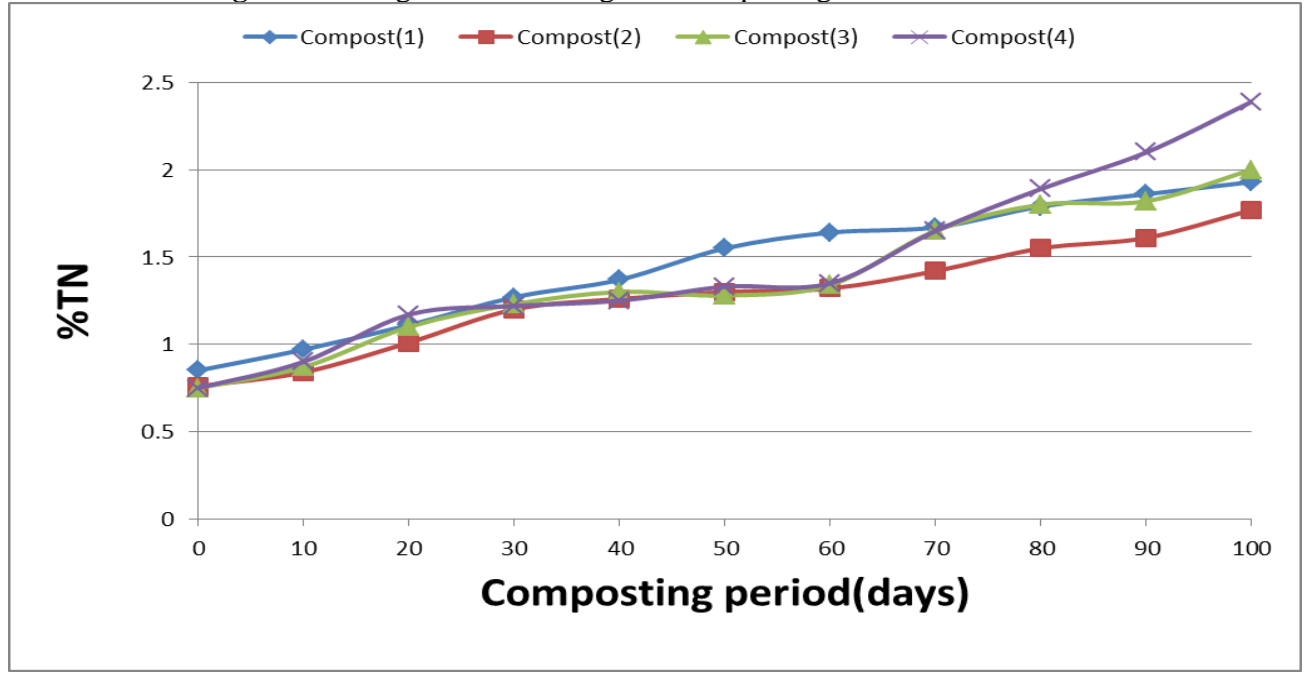


EC for all compost heaps being 2.3, 2.08, 2.04 and $2.1 \mathrm{ds} \mathrm{m}^{-1}$ for composting treatment $\mathrm{T} 1, \mathrm{~T} 2$, T3 and T4, respectively. The compost heaps showed regular increases in EC through the composting period. The composting materials conductivity rates at end of composting period were $3.48,3.1,3.22$ and $3.32 \mathrm{ds} \mathrm{m}^{-1}$ for treatments $\mathrm{T} 1, \mathrm{~T} 2, \mathrm{~T} 3$ and $\mathrm{T} 4$, respectively. The increase in the electrical conductivity of all compost heaps due to the mineralization of organic matter, which increased concentration of soluble salts (Chan et al., 2016). On the other hand, addition of RP decreased the EC to low degrees in the composts with an increase in RP amendment level compared to $\mathrm{C} 1$ ( $\mathrm{Lu}$ et al., 2014).

\subsubsection{Changes in Total organic carbon (TOC)}

The TOC concentration (Figure 5) declined slightly for all treatments, similar results were found by (El-Din and Abo-Sedera, 2001; Estafanous, 2003 and Seoudi, 2013). The initial values of TOC were $42.61 \%, 45.05 \%$, $49.05 \%$ and $49.47 \%$ for composting T1, T2, T3 and $\mathrm{T} 4$, respectively. After compost maturity the TOC reached $29.9 \%, 26.1 \%, 24.2 \%$ and $24 \%$ for treatments $\mathrm{T} 1, \mathrm{~T} 2, \mathrm{~T} 3$ and $\mathrm{T} 4$, respectively this indicates that the rate of carbon loss was higher in T2 compared T1 that can be attributed to addition of RP into the composting mass. Also, the rate of carbon loss was higher in both T3 and T4 inoculated treatments with (B.megatherum) and (A. lipoferum + A. chroococcum + B.megatherum) respectively compared with $\mathrm{T} 1$ and $\mathrm{T} 2$. According to Tumuhairwe et al. (2009) large TOC losses suggest pronounced microbial activity in the former. Diaz et al. (2020) reported that during composting, $\mathrm{C}$ is a source of energy for microorganisms to build up cells.

\subsubsection{Changes in total nitrogen (TN)}

Data in Fig. 6 showed changes ensued in total nitrogen percentage during different times of the composting process. Data shows that the percentage of TN regularly increased during the composting process. The increase in nitrogen percentage in different heaps may be caused to a concentration impact caused by active decomposable of the facilely degradation carbonaceous substrates, Resulting a decrease in the mass of the compost heaps (Pramanik et al., 2007 and Zhong et al., 2018). In general, during the first 60 days of composting the $\mathrm{TN}$ concentration shows a slight increase in treatment $\mathrm{T} 1$ compared with other treatments. Whereas the increase ratio was $48.17 \%, 42.42 \%, 44 \%$ and $44.4 \%$ for treatments $\mathrm{T} 1, \mathrm{~T} 2, \mathrm{~T} 3$ and $\mathrm{T} 4$, respectively. This decrease in TN in treatments $\mathrm{T} 2, \mathrm{~T} 3$ and T4 may be due to the addition of Rock Phosphate containing a lesser amount of $\mathrm{N}$ (Biswas et al., 2009). On the other hand, the reason might be the intense $\mathrm{NH}_{3}$ emission due to rock phosphate alkalinity (Wu et al., 2017). After an initial heat up period of 60 days, enrichment of compost by B.megatherum (T3) and $A$. lipoferum + A. chroococcum + B.megatherum (T4) run to increases in nitrogen content like compared to the T2 treatment. Whereas, the inoculation with (B.megatherum) alone leads to an increase of $11.5 \%$ over $\mathrm{T} 2$. This increase can be attributed to carbon losses during the process of composting. The main increase in nitrogen content was shown in the treatment $\mathrm{T} 4$ that inoculated with (A. lipoferum + A. chroococcum + B.megatherum) which showed an increase of $25.94 \%$ in nitrogen over the T2. The found results may be defended by non-symbiotic nitrogen fixing activities affected by A. chroococcum and A.lipoferum (Li et al., 2020 and Seoudi, 2013). Madusari et al. (2020) showed that the nitrogen content in compost with the addition of Azotobacter is 
slightly higher than compost without the addition of Azotobacter.

\subsubsection{Changes in $\mathrm{C} / \mathrm{N}$ ratio}

One of the often-used parameters to assess the rate of de-composition in the composting process is the $\mathrm{C} / \mathrm{N}$ ratio since it can reflect the maturity of the composted materials. Figure (7) shows the decrease in $\mathrm{C} / \mathrm{N}$ values in all treatments due to the mineralization of organic matter. The initial $\mathrm{C} / \mathrm{N}$ ratio was $61: 1$ for all composting treatments, and the final values of total $\mathrm{C} / \mathrm{N}$ ratio after the 100 days were $15: 1,14: 1,12: 1$ and 10:1 for composting treatments $\mathrm{T} 1, \mathrm{~T} 2, \mathrm{~T} 3$ and $\mathrm{T} 4$, respectively. The treatment $\mathrm{T} 4$ recorded the lowest value of $\mathrm{C} / \mathrm{N}$ ratio (10:1), and this may be attributed to higher carbon loss with microbial activity and increase in total nitrogen. A C/N ratio of less than 20 is considered as mature and can be used without any restriction. Although a $\mathrm{C} / \mathrm{N}$ ratio of 10 to 20 normally indicates as being in the range of the mature level, the higher ratio cannot be concluded, as the compost is not mature enough (Chen et al., 2011 and Iqbal et al., 2015).

\subsubsection{Changes in available phosphorus $(P)$}

The data in the fig.8. Show that the available phosphorus increased significantly in all treatments during composting irrespective of the treatments, in general the results showed that the enriched compost with rock phosphate (RP) treatments T2, T3 and T4 contains a much greater amount of available phosphorus compared to treatment $\mathrm{T} 1$. This may be due to the melting of RP during composting, which led to the release of $\mathrm{H}_{2} \mathrm{PO}_{4}$ and $\mathrm{Ca}^{+2}$ necessary for plant growth (Mahimairaja et al., 1994). Also, hydrogen $\left(\mathrm{H}^{+}\right)$ions emitted from organic acids during composting could be responsible for improving RP dissolution Likewise, available phosphorus release from RP can be increased through the production of weak carbonic acid, as carbon dioxide is released during the composting process (Alloush, 2003). Also, the results show inoculation with bacteria in treatments $\mathrm{T} 3$ and $\mathrm{T} 4$ significant increase in phosphorus availability compared with uninoculated treatments ( $\mathrm{T} 1$ and $\mathrm{T} 2$ ). At the end of the composting period the treatments increased after Inoculation of bacteria at a ratio $33.1 \%, 47.4 \%, 52.7 \%$ and $54.6 \%$ for heaps $\mathrm{T} 1$, $\mathrm{T} 2, \mathrm{~T} 3$ and $\mathrm{T} 4$, respectively. (Babana and Antoun, 2006) indicated that RP-enriched fertilizers inoculated with PSM had significantly larger quantities of $\mathrm{P}$ than those without inoculation, which may be a result of solubilization of P by PSM due to production of organic acids, namely citric, acetic, tartaric, oxalic, gluconic, lactic and a-ketogluconic acids.

\subsubsection{Changes in Total Potassium (TK)}

Figure 9, A gradual increase of TK in all treatments in a semi-constant pattern until the end of this increase could be due to the release of potassium from organic materials. The amount of increase in TK was in the range of $62.7-75.9 \%$ during the composting period. In general, the TK increase in prepared compost was in the order: $\mathrm{T} 1>\mathrm{T} 4>\mathrm{T} 3>\mathrm{T} 2$. The increase in T1 (not enriched with RP and without inoculation bacteria) can be attributed to the microbial decomposition of the organic matter and the decrease in the dry mass of the waste mixture and the mineralization processes (Gusain et al., 2018). 
Figure 7. Changes in $\mathrm{C} / \mathrm{N}$ ratio of compost heaps during composting.

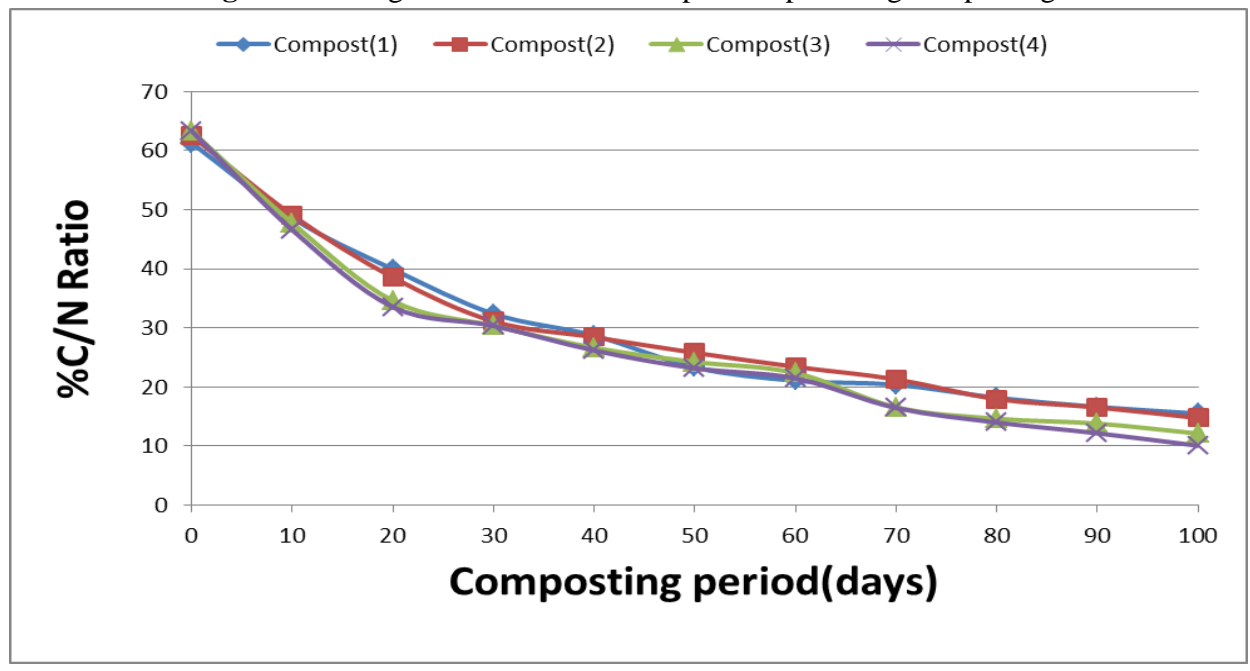

Figure 8. Changes in available $(\mathrm{P})$ of compost heaps during composting.

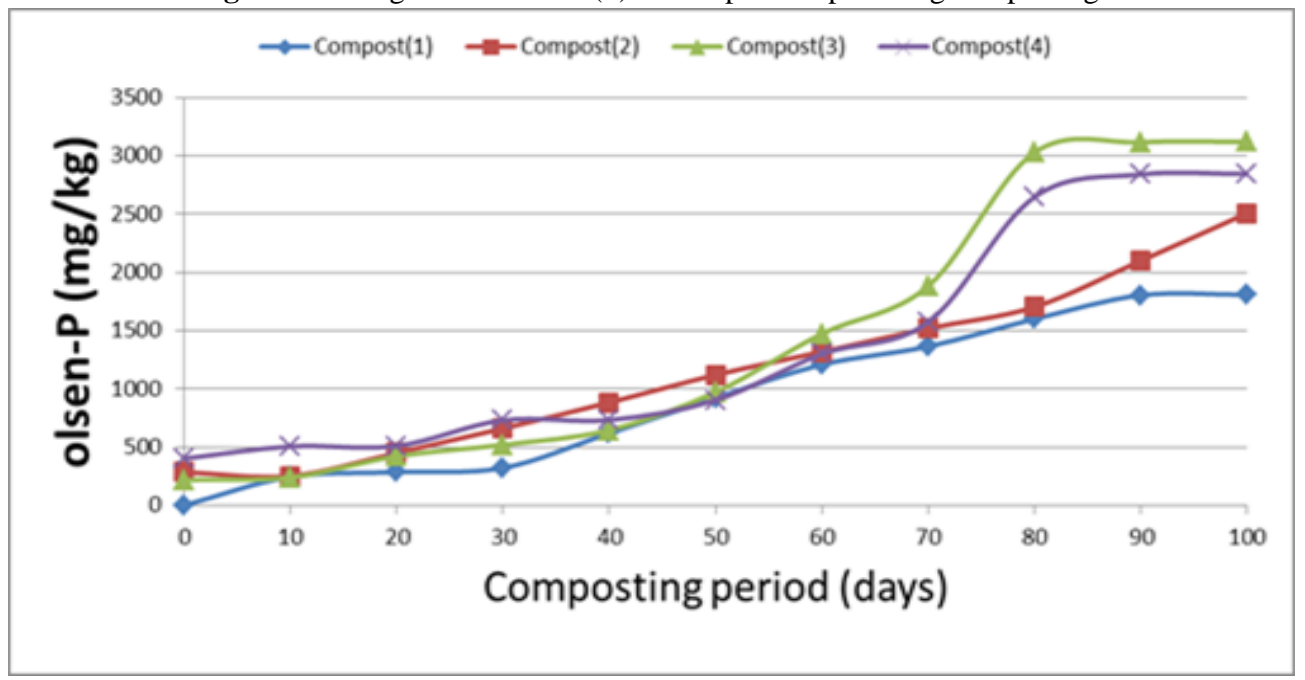

Figure 9. Changes in (TK) of compost heap s during composting.

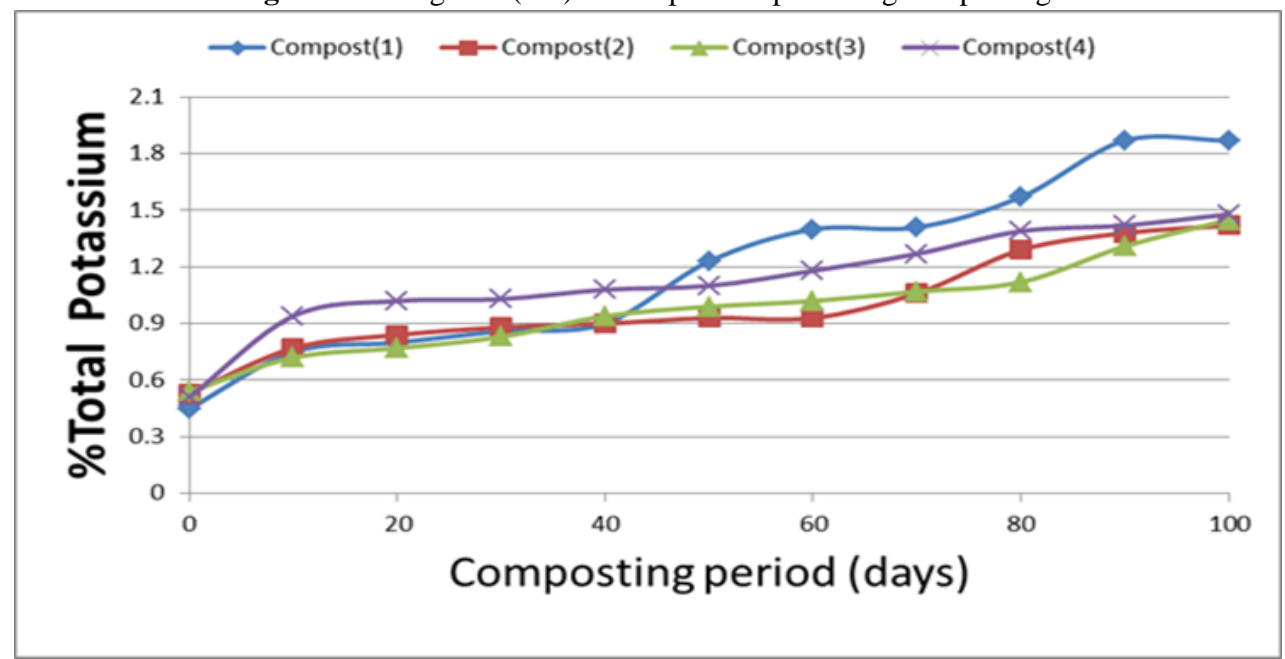




\section{Conclusion}

In conclusion, the present study recommended that the composting of corn residues could be considered an option of waste management that is cheap, environmentally friendly and furthermore produces high value compost use as alternative chemical fertilizers. Also, adding rock phosphate and plant growth-promoting rhizobacteria to corn residues during composting improve nutritional value of the resulting compost.

\section{References}

Achal, V., Savant, V. V. and Reddy, M. S. (2007) 'Phosphate solubilization by a wild type strain and UV-induced mutants of Aspergillus tubingensis' Soil Biology and Biochemistry, 39(2), pp. 695-699.

Adesemoye, A. O., Obini, M. and Ugoji, E.(2008) 'Comparison of plant growthpromotion with Pseudomonas aeruginosa and Bacillus subtilis in three vegetables' Brazilian Journal of Microbiology, 39(3), pp. 423-426.

Alloush, G.A. (2003) 'Dissolution and effectiveness of phosphate rock in acidic soil amended with cattle manure' Plant and Soil 251, pp. 37-46.

Babana, A.H. and Antoun, H. (2006) 'Effect of Tilemsi phosphate rock-solubilizing microorganisms on phosphorus uptake and yield of field-grown wheat (Triticum aestivum L.) in Mali' Plant Soil 287: pp. 51-58.

Biswas, D. R., Narayanasamy, G., Datta, S. C., Singh, G., Begum, M., Maiti, D.,Mishra, A. and Basak, B. B.(2009) 'Changes in nutrient status during preparation of enriched organo mineral fertilizers using rice straw, low-grade rock phosphate, waste mica, and phosphate solubilizing microorganism'
Communications in soil science and plant analysis, 40(13-14), pp. 22852307.

Biswas, D. R. (2011) 'Nutrient recycling potential of rock phosphate and waste mica enriched compost on crop productivity and changes in soil fertility under potato soybean cropping sequence in an Inceptisol of IndoGangetic Plains of India' Nutrient Cycling in Agroecosystems, 89(1), pp. 15-30

Chan, M. T., Selvam, A. and Wong, J. W. (2016) 'Reducing nitrogen loss and salinity during 'struvite'food waste composting by zeolite amendment' Bioresource technology, 200, pp. 838844.

Chen, L., De Haro, M.M., Moore, A. and Falen, C. (2011) 'The composting process: dairy compost production and use in Idaho CIS 1179'. University of Idaho.

Diaz, L. F., Golueke, C. G., Savage, G. M., and Eggerth, L. L. (2020) 'Composting and recycling municipal solid waste' CRC Press.

El-Din, S.M.S.B. and Abo-Sedera, S.A. (2001) 'Acceleration of composting of sugar beet haulms using two highly effective cellulose decomposing microorganisms' Egyptian Journal of Microbiology, 36(2), pp. 161-174

Estafanous, A.N. (2003) 'Amendment of rice straw with rock phosphate and certain microbial inoculants for production of high quality compost'. Egypt. J. Appl. Sci., 18, pp. 441-455.

Fogarty, A.M. and Tuovinen, O.H. (1991) 'Microbiological degradation of pesticides in yard waste composting' Microbiology and Molecular Biology Reviews, 55(2), pp. 225-233. 
Gaind, S., Pandey, A. K. and Lata. (2006) 'Microbial biomass, P-nutrition, and enzymatic activities of wheat soil in response to phosphorus enriched organic and inorganic manures' Journal of Environmental Science and Health Part B, 41(2), pp. 177-187.

Gautam, S.P., Bundela, P.S., Pandey, A.K., Awasthi, M.K. and Sarsaiya, S. (2010) 'Municipal solid waste management in central India' Journal Applied Science Research, 6(8), pp. 1029-1033.

Gusain, R., Pandey, B. and Suthar, S. (2018) 'Composting as a sustainable option for managing biomass of aquatic weed Pistia: A biological hazard to aquatic system' Journal of Cleaner Production, 177, pp. 803-812.

Hamid, H., Ashtashila, S., Ashtaputre, N. M.and Mageshwaran, V. (2020) 'Storability of bio enriched compost prepared from cotton stalks' Journal of Cotton Research and Development, 34(2), pp. 301-308.

Hanajima, D., Kuroda, K., Fukumoto, Y. and Haga, K. (2006) 'Effect of addition of organic waste on reduction of Escherichia coli during cattle feces composting under high-moisture condition' Bioresource Technology, 97, pp. 1626-1630.

Hassan, H. B. A., el Gebaly, M. R., Ghani, S. S. A.and Hussein, Y. M. M. (2014) 'An economic study of recycling agricultural wastes in Egypt' Middle East J Agric Res, 3(3), pp. 592-608.

Huerta-Pujol, O., Soliva, M., MartínezFarré, F. X., Valero, J. and López, M. (2010) 'Bulk density determination as a simple and complementary tool in composting process control' Bioresource technology, 101(3), pp. 995-1001.
Iqbal, M.K., Nadeem, A., Sherazi, F. and Khan, R.A. (2015) 'Optimization of process parameters for kitchen waste composting by response surface methodology' International Journal of Environmental Science and Technology, 12(5), 1759-1768

Jackson, M. L. (1973) 'Soil chemical analysis' (Indian Edition).

Juárez, M. F. D., Gómez-Brandón, M.and Insam, H. (2015) 'Merging two waste streams, wood ash and biowaste, results in improved composting process and end products'. Science of the Total Environment, 511, pp. 91-100.

Khan, N. and Bano, A. (2016) 'Modulation of phytoremediation and plant growth by the treatment with PGPR, Ag nanoparticle and untreated municipal wastewater' International journal of phytoremediation, 18(12), 1258-1269.

Kutsanedzie, F.G., Rockson, N.K. and Achio, S. (2012) 'Comparison of compost maturity, microbial survival and health hazards in two composting systems' Journal of Microbiology, Biotechnology and Food Science, 2 (1): pp. 175-193.

Larney, F. J., Olson, A. F., Carcamo, A. A. and Chang, C. (2000) 'Physical changes during active and passive composting of beef feedlot manure in winter and summer' Bioresource Technology, 75(2), pp. 139-148.

Lazcano, C., Gómez-Brandón, M.and Domínguez, J. (2008) 'Comparison of the effectiveness of composting and vermicomposting for the biological stabilization of cattle manure' Chemosphere, 72(7), pp. 1013-1019.

Li, X., Shi, X. S., Lu, M. Y., Zhao, Y. Z., Guo, R. B. and Peng, H. (2020) 'Improved nitrogen conservation capacity during composting of dairy 
manure amended with oil shale semicoke as the porous bulking agent' Journal of hazardous materials, 388 , 121742.

Liu, D., Zhang, R., Wub, H., Xu, D., Tang, Z., Yu, G., Xu, Z., and Shen, Q. (2011) 'Changes in biochemical and microbiological parameters during the period of rapid composting of dairy manure with rice chaff' Bioresource Technology, 102(19): pp. 9040-9049.

Lu, D., Wang, L., Yan, B., Ou, Y., Guan, J., Bian, Y. and Zhang, Y. (2014) 'Speciation of $\mathrm{Cu}$ and $\mathrm{Zn}$ during composting of pig manure amended with rock phosphate' Waste management, 34(8), pp. 1529-1536.

Madusari, S., Firmanto, Z. and Sinuraya, R. (2020) 'Oil Palm Pressed Fiber Valorization: Improving Fiber Processing in Composting with Azotobacter for Use in Potting Media of Brassica rapa' Journal of Applied Sciences and Advanced Technology, 2(3), pp. 65-72.

Mahimairaja, S., Bolan, N. S. and Hedley, M. J. (1994) 'Dissolution of phosphate rock during the composting of poultry manure: an incubation experiment' Fertilizer Research, 40(2), pp. 93-104.

Møller, H. B., Sommer, S. G. and Andersen, B. H. (2000) 'Nitrogen mass balance in deep litter during the pig fattening cycle and during composting' The Journal of Agricultural Science, 135(3), pp. 287296.

Nappi, P. and Barberis, R. (1992) 'Compost as growing medium: chemical, physical and biological aspects' In International Symposium on Horticultural Substrates other than Soil in situ, 342, pp. 249256.
Narayanasamy, G. and Biswas, D. R. (1998) 'Phosphate rocks of India: Potentialities and constraints' Fertiliser news, 43(10). Page, A.L., Miller, R.H. and Keeny, D.R. (1982) 'Methods of Soil Analysis' Part 2. Soil Sci. Soc. Amer. Inc. Madison, Wisconsin, USA.

Pramanik, P., Ghosh, G. K., Ghosal, P. K.and Banik, P. (2007) 'Changes in organic- $\mathrm{C}, \mathrm{N}, \mathrm{P}$ and $\mathrm{K}$ and enzyme activities in vermicompost of biodegradable organic wastes under liming and microbial inoculants' Bioresource technology, 98(13): pp. 2485-2494.

Preusch, P.L., Takeda, F. and Tworkoski, T.J. (2004) ' $\mathrm{N}$ and $\mathrm{P}$ uptake by strawberry plants grown with composted poultry litter' Scientia horticulturae, 102(1): pp. 91-103.

Puente, M.E., Bashan, Y., Li, C.Y. and Lebsky, V.K. (2004) 'Microbial populations and activities in the rhizoplane of rock-weathering desert plants. I. Root colonization and weathering of igneous rocks' Plant Biology, 6(5), pp. 629-642.

Qian, X., Shen, G., Wang, Z., Guo, C., Liu, Y., Lei, Z. and Zhang, Z. (2014) 'Cocomposting of livestock manure with rice straw: characterization and establishment of maturity evaluation system' Waste management, 34(2), pp. 530-535.

Raviv, M., Tarre, S., Geler, Z. and Shelef, G. (1987) 'Changes in some physical and chemical properties of fibrous solids from cow manure and digested cow manure during composting' Biological Wastes, 19(4), pp. 309-318. Reddy, M.S., Kumar, S. and Babita, K. (2002) 'Bio-solubilization of poorly soluble rock phosphates by Aspergillus tubingensis and Aspergillus niger' 
Bioresource technology, 84(2), 187189.

Rodrigues, A. M., Ferreira, L. J., Fernando, A. L., Urbano, P. and Oliveira, J. S. (1995) 'Co-composting of sweet sorghum biomass with different nitrogen sources' Bioresource technology, 54(1), 21-27.

Sánchez-Monedero, M. A., Roig, A., Paredes, C. and Bernal, M. P. (2001) 'Nitrogen transformation during organic waste composting by the Rutgers system and its effects on $\mathrm{pH}, \mathrm{EC}$ and maturity of the composting mixtures' Bioresource technology, 78(3), 301-308.

Seoudi, O. A. T. (2013) 'Enhancement of Cotton Stalks Composting with Certain Microbial Inoculations' Journal of Advanced Laboratory Research in Biology, 4(1), 2635.

Shahzad, S.M., Khalid, A., Arshad, M., Khalid, M. and Mehboob, I. (2008) 'Integrated use of plant growth promoting bacteria and Penriched compost for improving growth, yield and nodulating of Chickpea' Pakistan Journal of Botany, 40 (4), pp. 1441-1735.

Shrivastava, M., Kale, S.P. and D'Souza, S.F. (2011) 'Rock phosphate enriched postmethanation bio-sludge from kitchen waste based biogas plant as $\mathrm{P}$ source for mungbean and its effect on rhizosphere phosphatase activity'. European Journal of Soil Biology, 47(3), pp. 205-212.

Smith, J.L., Papendick, R.I., Bezdicek, D.F. and Lynch, J.M. (1993) 'Soil organic matter dynamics and crop residue management' In Soil microbial ecology: Applications in agricultural and environmental Management. 23, pp. 65-94

Smith, D. C. and Hughes, J. C. (2002) 'Changes in chemical properties and temperature during the degradation of organic wastes subjected to simple composting protocols suitable for small-scale farming, and quality of the mature compost' South African Journal of Plant and Soil, 19(2), pp. 53-60.

Spencer, J. L. and Van Heyst, B. J. (2013) 'Effect of different intermediate amendments on $\mathrm{pH}$ and ammonia emissions of composted poultry mortalities' Journal of Applied Poultry Research, 22(4), pp. 700-714.

Tumuhairwe, J. B., Tenywa, J. S., Otabbong, E.and Ledin, S. (2009) 'Comparison of four low-technology composting methods for market crop wastes' Waste Management, 29(8), pp. 2274-2281.

Wu, J., He, S., Liang, Y., Li, G., Li, S., Chen, S. and $\mathrm{Hu}$, J. (2017) 'Effect of phosphate additive on the nitrogen transformation during pig manure composting' Environmental Science and Pollution Research, 24(21), pp. 17760-17768.

Zayed, G., and Abdel-Motaal, H. (2005) 'Bioactive composts from rice straw enriched with rock phosphate and their effect on the phosphorous nutrition and microbial community in rhizosphere of cowpea' Bioresource Technology, 96(8), pp. 929935.

Zhang, L. and Sun, X. (2015) 'Effects of earthworm casts and zeolite on the twostage composting of green waste' Waste Management, 39, pp. 119-129.

Zhong, X. Z., Ma, S. C., Wang, S. P., Wang, T. T., Sun, Z. Y., Tang, Y. Q. and Kida, K. (2018) 'A comparative study of composting the solid fraction of dairy manure with or without bulking material: performance and microbial community dynamics' Bioresource technology, 247, pp. 443-452. 